\title{
Further steps of Cryptorchestia garbinii invasion in Polish inland waters with insights into its molecular diversity in Central and Western Europe
}

\author{
Tomasz Rewicz ${ }^{1,2, *}$, Jarosław Brodecki ${ }^{1}$, Karolina Bącela-Spychalska ${ }^{1}$, Alicja Konopacka ${ }^{1}$ \\ and Michał Grabowski ${ }^{1}$ \\ ${ }^{1}$ University of Lodz, Department of Invertebrate Zoology and Hydrobiology, 12/16 Banacha str., 90-237 Lodz, Poland \\ ${ }^{2}$ University of Guelph, Centre for Biodiversity Genomics, 50 Stone Road East Guelph, ON N1G2W1, Canada
}

Received: 18 November 2019 / Accepted: 27 February 2020

\begin{abstract}
Cryptorchestia garbinii Ruffo, Tarocco and Latella, 2014 (Amphipoda: Talitridae), a semiterrestrial amphipod, reported (as Orchestia cavimana Heller, 1865) from the Polish inland waters, e.g., the lowermost Vistula River, for the first time in 2009. Now, we have reported this species from the upper Oder River, which is c.a. $350 \mathrm{~km}$ SE from the closest known localities near Berlin, Germany. We confirmed its identity by the DNA barcodes and showed that all individuals found so far in other countries in Central and Western Europe represent the same haplotype, excluding a singleton from the locus typicus of this species in Lake Garda, Italy.
\end{abstract}

Keywords: Amphipoda / Talitridae / beach hoppers / non-indigenous species / DNA barcoding

\begin{abstract}
Résumé - Nouvelles étapes de l'invasion de Cryptorchestia garbinii dans les eaux intérieures polonaises avec un aperçu de sa diversité moléculaire en Europe centrale et occidentale. Cryptorchestia garbinii Ruffo, Tarocco et Latella, 2014 (Amphipoda : Talitridae), un amphipode semiterrestre, signalé (sous le nom d'Orchestia cavimana Heller, 1865) dans les eaux intérieures polonaises, par exemple, dans la Vistule la plus aval, pour la première fois en 2009. Nous avons maintenant signalé cette espèce dans le cours supérieur de l'Oder, qui se trouve à environ $350 \mathrm{~km}$ au sud-est des localités connues les plus proches, près de Berlin, en Allemagne. Nous avons confirmé son identité par les codes barres ADN et montré que tous les individus trouvés jusqu'à présent dans d'autres pays d'Europe centrale et occidentale représentent le même haplotype, à l'exception d'un singleton du locus typicus de cette espèce dans le lac de Garde, en Italie.
\end{abstract}

Mots-clés : Amphipoda / Talitridae / puce de plage / espèces non indigènes / code-barres ADN

\section{Introduction}

The Oder is the second biggest river in Poland and thirtieth in Europe with a length of $854 \mathrm{~km}$ and the drainage area of $1,18,861 \mathrm{~km}^{2}$. The river flows into the Baltic Sea and is the most significant waterway in Poland, navigable on most of its length. The Oder is fed, among others, by such rivers as Warta, Nysa Łużycka, Bóbr and connected through artificial channels to Havel, Spree, Vistula and Kłodnica rivers, which supports the migration of non-indigenous species through the so-called Central Invasion Corridor (CIC) sensu Bij de Vaate et al. (2002). Additionally, the Szczecin Lagoon, being a part of the

\footnotetext{
*Corresponding author: tomasz.rewicz@biol.uni.lodz.pl
}

Oder deltaic system (Osaduczuk, 2004), with a large traffic port playing an important role in marine and inland shipping, is considered to be an essential gateway for the introduction of invasive species (Gruszka, 1999; Galil et al., 2008; Gruszka et al., 2013; Messner and Zettler, 2018). The number of alien macroinvertebrate species in the Oder River is still growing. Altogether, at least 33 non-indigenous species have been so far identified in the Oder and in the Szczecin Lagoon (Gruszka, 1999; Szlauer-Łukaszewska and Grabowski, 2012; Jabłońska et al., 2015; Pabis et al., 2017; Szlauer-Łukaszewska et al., 2017; Jabłońska et al., 2018; Cebulska and Krodkiewska, 2019). Among them, nine amphipod species were identified: Chelicorophium curvispinum (Sars G.O., 1894), Dikerogammarus villosus (Sowinsky, 1894), D. haemobaphes (Eichwald, 1841), Echinogammarus trichiatus (Martynov, 1932), 


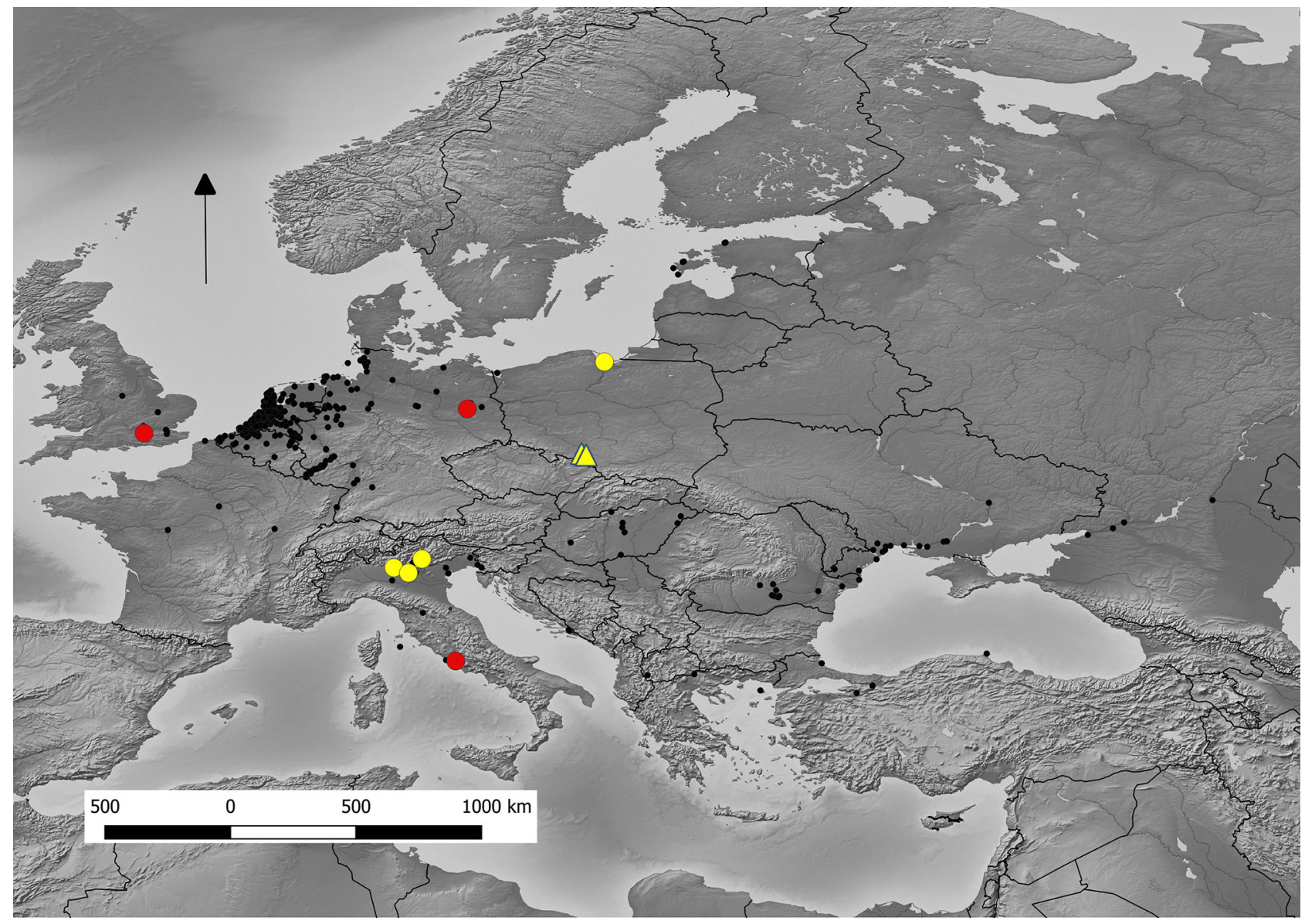

Fig. 1. Distribution of Cryptochestia garbinii in Europe and sequences analyzed in this study. Yellow triangles - new records from the upper Oder in Krapkowice and Zdzieszowice, yellow circles - other own records of the species with DNA barcodes; red circles - sequences obtained from the BOLD database, black dots - previously known records of the species (combined literature and personal communications data - see details in Tab. S1).

Melita nitida Smith, 1873, Obesogammarus crassus (Sars G.O., 1894), Pontogammarus robustoides (Sars, 1894), Gammarus tigrinus Sexton, 1939 and Cryptorchestia garbinii (Orchestia cavimana) Ruffo, Tarocco and Latella, 2014 (Konopacka et al., 2009; Rachalewski et al., 2013; Zettler and Zettler, 2017).

Lowry and Fanini (2013) erected the genus Cryptorchestia to accommodate semi-terrestrial and terrestrial species, associated with fresh and brackish waters, set apart from the typically marine, supralittoral beach hoppers of the genus Orchestia Leach, 1814 (see Davolos et al., 2018a and literature therein). Currently, Cryptorchestia cavimana (Heller, 1865) is considered as endemic to Cyprus (Ruffo et al., 2014; Davolos et al., 2017). In contrast, Cryptorchestia garbinii (encompassing records of $O$. cavimana outside Cyprus), has a wide European distribution including sea coasts, deltas and estuaries of the Baltic, Black, Marmara, Mediterranean, and North seas (Herkül et al., 2006; Konopacka et al., 2009; Davolos et al., 2018a, Tab. S1) (Fig. 1). Cryptorchestia garbinii is continually spreading in the European inland freshwater ecosystems, such as large rivers (e.g., Dnieper, Danube, Thames, Rhine) (Rehage, 1987; Martens et al., 1999; Ruffo et al., 2014) and lakes (e.g., Albano, Balaton, Doirani, Garda, Ohrid,
Prespa) (Carausu et al., 1955; Karaman, 1993; Juhász et al., 2006; Ruffo et al., 2014; Davolos et al., 2018a).

In Poland, the first observations come from the brackish waters of the Szczecin Lagoon, the islands of Wolin and Uznam, the Vistula Lagoon, the Martwa Wisła (Jażdżewski and Konopacka, 1995) and the Puck Bay (Spicer and Janas, 2006). The first record from inland waters (as an O. cavimana) was provided by Konopacka et al. (2009) from the lowest part of the Vistula River, $3 \mathrm{~km}$ upstream from its mouth (Fig. 1). No further localities from the Polish inland waters have been registered since then. Even Tykarska et al. (2019), in their work about the distribution of talitrids at the Polish Baltic coast, regarded this species as restricted only to the Vistula mouth.

Our study aims to document the southward spread of $C$. garbinii to the upper Oder river as well as to provide first molecular confirmation for the species identity in Poland. Taxonomic consistency is crucial for the studied species as its assignments to $O$. cavimana are still ongoing. Even four years after the taxonomic revision of Orchestia and redescription of C. garbinii and C. cavimana (Lowry and Fanini, 2013, Ruffo et al., 2014), C. garbinii is still commonly reported as $O$. cavimana (Davolos et al., 2018b), generating more confusions 

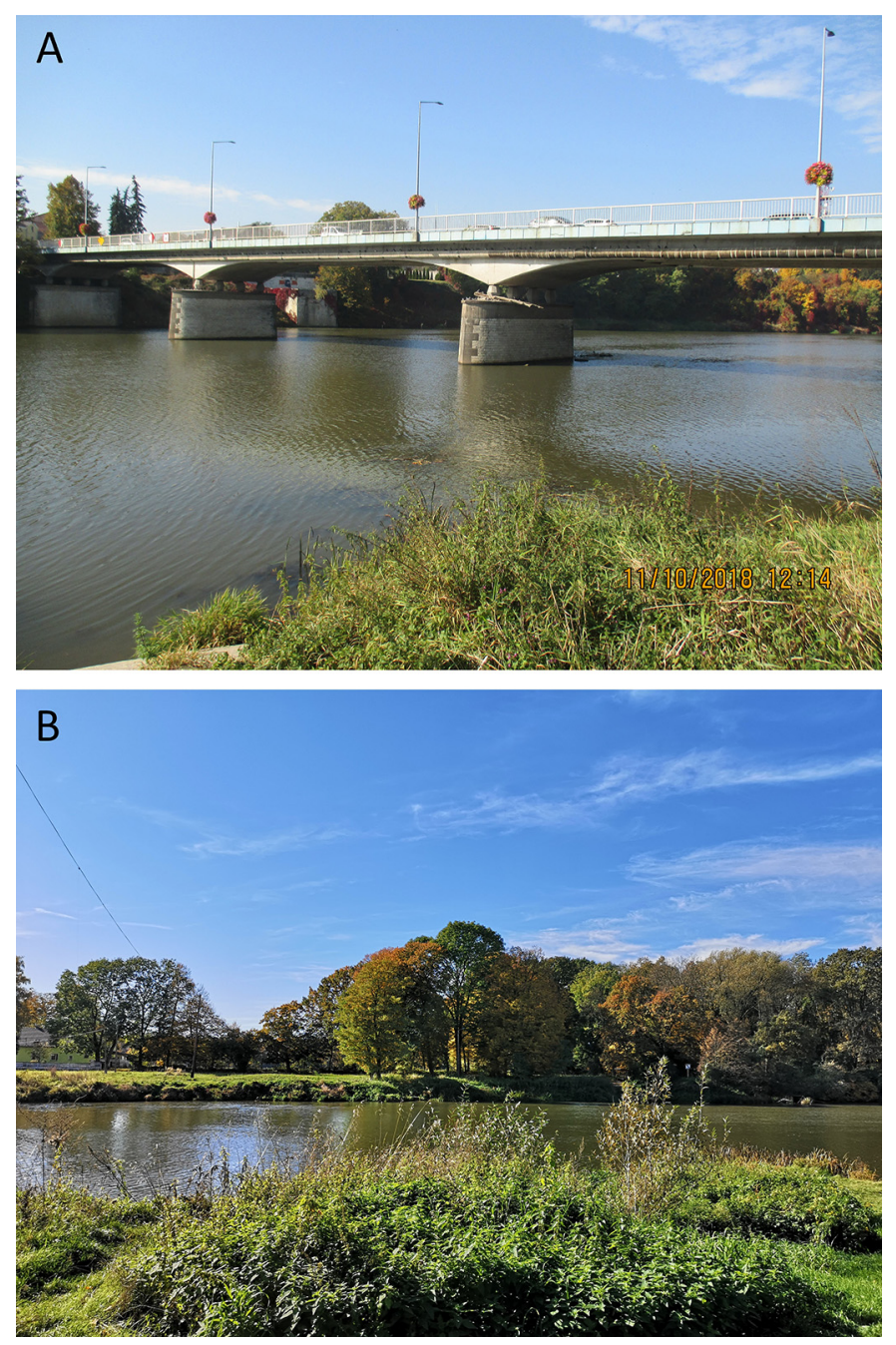

Fig. 2. Sampling localities on the Oder River. A Krapkowice, B Zdzieszowice.

(e.g., Ramm and Scholtz, 2017; Jelassi et al., 2018). Molecular identification based on the portion of cytochrome oxidase (COI) gene used as a DNA barcode as well as comparison with other European sequences of $C$. garbinii (including locus typicus) can be sufficient to reveal species assignment and potential cryptic diversity. Such a method has already been successfully implemented in studies upon various invasive invertebrates, including amphipods (e.g., Rewicz et al., 2015, 2016; 2019; Hupało and Grabowski, 2018; Mauvisseau et al., 2019).

\section{Materials and methods}

The individuals of Cryptorchestia garbinii, were collected on the groin near Krapkowice (11th of October, 2018) and Zdzieszowice (17th of October, 2019) (Fig. 2). The samples were collected by hand and with a benthic hand net from plant debris and grassroots along the water's edge and from among the stones and instantly preserved in $96 \%$ ethanol. Additional specimens that originated from previous sampling campaigns:
Poland 2009, 2016 as well as Italy 2011, 2016 were used (Tab. 1, Fig. 1). All the material was identified to the species level under the Nikon SMZ-800 stereomicroscope, based on available literature (i.e., Spicer and Janas, 2006; Ruffo et al., 2014) and has been stored in the permanent collection of the Department of Invertebrate Zoology and Hydrobiology, University of Lodz, Poland.

The total DNA was extracted from the fifth pereiopod or pleopods of the dissected individuals. DNA extraction, PCR reaction, enzymatic purification, and sequencing was proceeded following Rewicz et al. (2019). To verify the identification of obtained sequences, we used the BLAST tool (Altschul et al., 1990). Then, the sequences were edited and aligned using Geneious 10.2.6 software package (Kearse et al., 2012), and deposited in GenBank under accession numbers MK721831-MK721847; MN701467 - MN701476. The COI haplotypes were identified using the DnaSP v5 software (Librado and Rozas, 2009). All 22 sequences were deposited in the online database of the Barcode of Life Data Systems (BOLD) Systems (Ratnasingham and Hebert, 2007). We obtained the Barcode Index Numbers (BIN) which are indexing DNA sequences based on the genetic distance approach (Ratnasingham and Hebert, 2013). Additional COI sequences of $C$. garbinii (eight individuals), as well as the three outgroup sequences, were acquired from GenBank and BOLD (see Tab. 1). Sequences were finally trimmed to $500 \mathrm{bp}$. Phylogenetic tree was constructed in MEGA 6 (Tamura et al., 2013) using the neighbor-joining method (Saitou and Nei, 1987) based on the K2p distance (Kimura, 1980) with a bootstrap test performed on 1000 replicates (Fig. 3). Relevant voucher information is accessible through the public dataset "DS-CGARPOL" (DOI: http://dx.doi.org/10.5883/ DS-CGARPOL) in the Barcode of Life Data Systems (BOLD; http://v4.boldsystems.org).

\section{Results}

DNA barcoding confirmed the identity of all the 22 individuals identified as $C$. garbinii (Fig. 3). We have found only two haplotypes in the analyzed dataset. Almost all individuals from Great Britain, Italy, Germany, and Poland represented one haplotype. Only in the locality from Lake Garda (locus typicus), we found another unique haplotype, differing by a single mutation from the common one (Fig. 3). All the sequences grouped under one BIN (BOLD: AAD8710) which is up to now the only BIN known from the BOLD publically available data and is widespread in Western and Central Europe.

\section{Discussion}

The known distribution of $C$. garbinii stretches to the Balkans and the Ponto-Caspian region on the south-eastern part of Europe and Great Britain, France and Italy on the western part (Ruffo et al., 2014, own unpublished data). We can observe an ongoing spatial expansion of $C$. garbinii in Europe, as new records have been reported in recent years from northern Germany, Netherlands, Belgium, Poland, Baltic States, Ukraine, Balkan Peninsula and from Turkey (Herkül et al., 2006; 
T. Rewicz et al.: Knowl. Manag. Aquat. Ecosyst. 2020, 421, 17

Table 1. Material of Cryptorchestia garbinii, Cryptorchestia cavimana and two outgroup species used in our study. N - number of analyzed specimens.

\begin{tabular}{|c|c|c|c|c|c|c|c|}
\hline No & GenBank acc. & BOLD process ID & Locality & Latitude & Longitude & $\mathrm{N}$ & Reference \\
\hline & $\begin{array}{l}\text { Cryptorchestia garbinii Ruffo, Tarocco, \& } \\
\text { Latella, } 2014\end{array}$ & & & & & & \\
\hline 1. & MN701468, MN701472-MN701475 & WW234-08 - WW238-08 & $\begin{array}{l}\text { United Kingdom, } \\
\text { Medway estuary }\end{array}$ & 51.33 & -0.46 & 5 & BOLD public database \\
\hline 2. & EF989708 & GBCMA1151-08 & $\begin{array}{l}\text { Germany, Tegeler } \\
\text { Lake }\end{array}$ & 52.35 & 13.16 & 1 & Browne et al., 2007 \\
\hline 3. & JX094884, JX094873 & GBCMA6264-13, GBCMA6275-13 & Italy, Albano Lake & 41.74 & 12.67 & 2 & Wildish et al., 2012 \\
\hline 4. & MK721834 & AMPPL005-19 & Italy, Lake Iseo & 45.67 & 10.06 & 1 & This study \\
\hline 5. & $\begin{array}{l}\text { MK721836-MK721837, MK721840, } \\
\text { MK721842-MK721843, MK721847 }\end{array}$ & AMPPL006-19 - AMPPL011-19 & Italy, Lake Garda & 45.44 & 10.68 & 6 & This study \\
\hline 6. & MK721838, MK721845-MK721846 & AMPPL002-19 - AMPPL004-19 & $\begin{array}{l}\text { Italy, Lake } \\
\text { Caldonazzo }\end{array}$ & 46.03 & 11.24 & 3 & This study \\
\hline 7. & $\begin{array}{l}\text { MK721832-MK721833, MK721835, } \\
\text { MK721838-MK721839, MK721841, MK721844 }\end{array}$ & AMPPL012-19 - AMPPL017-19 & $\begin{array}{l}\text { Poland, Vistula } \\
\text { estuary }\end{array}$ & 54.33 & 18.93 & 6 & This study \\
\hline 8. & MK721831 & AMPPL001-19 & $\begin{array}{l}\text { Poland, Oder, } \\
\text { Krapkowice }\end{array}$ & 50.48 & 17.97 & 1 & This study \\
\hline \multirow[t]{7}{*}{9} & $\begin{array}{l}\text { MN701467, MN701469 - MN701471, } \\
\text { MN701476 }\end{array}$ & AMPPL123-19 - AMPPL127-19 & $\begin{array}{l}\text { Poland, Oder, } \\
\text { Zdzieszowice }\end{array}$ & 50.41 & 18.17 & 5 & This study \\
\hline & Cryptorchestia cavimana (Heller, 1865) & & & & & & \\
\hline & JX094880 & GBCMA6268-13 & Cyprus & 34.95 & 32.85 & 1 & Wildish et al., 2012 \\
\hline & Speziorchestia guancha (Stock \& Boxshall, 1989) & & & & & & \\
\hline & JX094882 & GBCMA6266-13 & Spain, Tenerife & 28.28 & -16.86 & 1 & Wildish et al., 2012 \\
\hline & Platorchestia platensis (Krøyer, 1845) & & & & & & \\
\hline & MF544024 & PPLA009-17 & Sweden, Vägeröd & 58.24 & 11.49 & 1 & Hupało and Grabowski, 2018 \\
\hline
\end{tabular}

Konopacka et al., 2009; Rewicz et al., 2016; GBIF, 2019; Davolos et al., 2018a; Fig. 1, Tab. S1). Revealing the presence of this talitrid in the upper Oder confirms its ongoing expansion. The question arises of what the source for this new population is. Cryptorchestia garbinii was recorded in the Szczecin Lagoon, Poland, more than 20 years ago by Jażdżewski and Konopacka (1995) and more recently in Tegeler See north-west from Berlin, Germany (Wolff and Scholtz, 2006). Tegeler See has a direct connection to the Oder river through Mittelland Canal, a wellknown part of the CIC (Bij de Vaate et al., 2002). Numerous Ponto-Caspian species, including amphipods, reached Western Europe through this watercourse (Grabowski et al., 2007; Leuven et al., 2009). Oppositely, the killer shrimp, Dikerogammarus villosus, used CIC to invade Germany and Oder river eastward from western Germany (Rewicz et al., 2015). Hence, both potential sources - Szczecin Lagoon and Tegeler See seem equally plausible.

The obtained DNA barcode sequences unequivocally support the identification of C. garbinii in Poland (Fig 3). The molecular diversity of this species in Central and Western Europe is quite interesting. Only two haplotypes have been identified in an area of more than $750000 \mathrm{~km}^{2}$, stretching N-S about $1360 \mathrm{~km}$ and W-E about $1300 \mathrm{~km}$ (Fig. 1). One of them is present all over the studied range, while the second haplotype occurs only in Lake Garda, which is a locus typicus of this species. Such low haplotype diversity may be, on the one hand, a result of fast colonization process, on another, a result of under-sampling. Davolos et al. (2017, 2018a) conducted studies upon phylogeny of the genus Cryptorchestia and found different haplotypes occurring in Lake Ohrid, Northern Macedonia, and in Turkey. However, since they used nuclear Histone 3, and the mitochondrial COI 3P markers, we cannot compare our data. Interestingly, $C$. garbinii and two other Cryptorchestia species, C. cavimana, and C. ruffoi, which are endemic to the east Mediterranean islands of Cyprus and Rhodes, respectively, form a monophyletic clade (Davolos et al., 2018a). That may suggest a potentially different place of origin and diversification of this species, than Western Europe (locus typicus). Studies upon another amphipod, Gammarus roeselii Gervais, 1835, pointed out the Balkan Peninsula as the most probable origin of the species (Grabowski et al., 2017). This region is regarded as an essential faunal biodiversity hotspots in Europe (e.g., Wysocka et al., 2013, 2014; Sworobowicz et al., 2015; Mamos et al., 2016; Jabłońska et al., 2020). The Pontic region was, on the other hand, the place of origin of Gammarus varsoviensis Jażdżewski, 1975 (Grabowski et al., 2012). Both amphipod species were described hundreds of kilometers westward (vicinity of Paris, France, and Warsaw, Poland, respectively) from their factual place of origin. In the case of both species, we can observe much higher molecular diversity in the real place of origin than in the recently colonized area. We can expect a similar situation in the case of $C$. garbinii, and further phylogeographic studies including individuals from the Ponto-Caspian and Balkan regions, are undeniably needed to solve this problem.

In conclusion, we provide the first molecular evidence of the presence of Cryptorchestia garbinii in Poland and insight into the molecular diversity of the species in Central and Western Europe. This species is in the spatial expansion stage in Europe, and its population structure, as well as wide-scale phylogeography (especially in the Balkans and in the PontoCaspian region), are still insufficiently known and require thorough molecular research. 


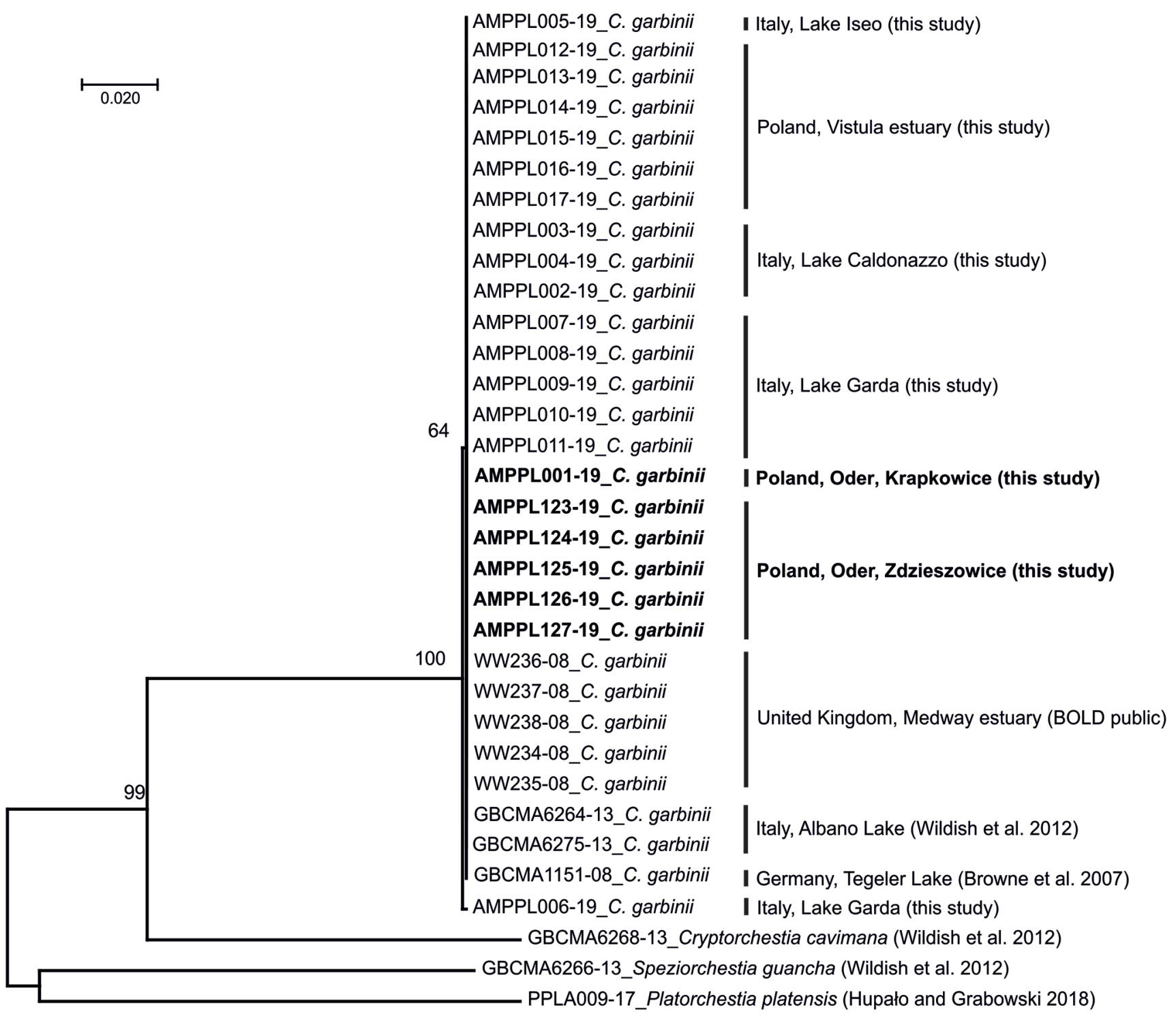

Fig. 3. Neighbor-joining tree based on COI K-2p distance for sequences of Cryptorchestia garbinii, C. cavimana, and two other talitrid outgroup species. Sequences from the Oder river are in bold. Each sequence name consists of two parts separated by a lower dash: (1) BOLD Process ID, (2) species name.

\section{Supplementary Material}

Supplementary table.

The Supplementary Material is available at https://www.kmaejournal.org/10.1051/kmae/2020009/olm.

Acknowledgments. We would like to thank Berenika Georgievová, Kamil Hupało, Ewa Janowska, Piotr Janowski, Tomasz Mamos, and Remi Wattier for their support in-field sampling as well as to Kamil Hupało and Halyna Morhun for their assistance in laboratory work. We would like to thank Andrii Khomenko, Halyna Morhun, Vadim Panov, Alexandr Prokin and Mikhail Son for information about occurrence data of Cryptorchestia garbinii in Ukraine and in Russia. The study was supported partially from the National Science Centre (Poland), projects 2018/31/D/NZ8/03061, 2014/15/B/NZ8/ 00266; Polish Ministry of Sciences and Higher Education grant N N304 350139 and partially from the internal funds of the University of Lodz. Tomasz Rewicz was supported by the Scholarship of the Polish National Agency for Academic Exchange (NAWA) at Bekker Programme nb. PPN/BEK/ 2018/1/00162/U/00001. Jarosław Brodecki participates in the University of Lodz programme for higher school students "Zdolny uczeń - świetny student".

\section{References}

Altschul SF, Gish W, Miller W, Myers EW, Lipman DJ. 1990. Basic local alignment search tool. J Mol Biol 215: 403-410. 
Bij de Vaate A, Jażdżewski K, Ketelaars HAM, Gollasch S, Van der Velde G. 2002. Geographical graphical patterns in range extension of Ponto-Caspian macroinvertebrate species in Europe. Can J Fish Aquat Sci 59: 1159-1174.

Browne WE, Haddock SHD, Martindale MQ. 2007. Phylogenetic analysis of lineage relationships among hyperiid amphipods as revealed by examination of the mitochondrial gene, cytochrome oxidase I (COI). Integr Comp Biol 47: $815-830$

Carausu S, Dobreanu E, Manolache C. 1955. Amphipoda forme salmastre si de apa dulce. Fauna Republicii Populare Romine. Crustacea 4: 1-409.

Cebulska K, Krodkiewska M. 2019. Further dispersion of the invasive alien species Corbicula fluminea (O. F. Müller, 1774) in the Oder River. Knowl Manag Aquat Ecosyst 420: 14.

Davolos D, De Matthaeis E, Latella L, Vonk R. 2017. Cryptorchestia ruffoi sp. n. from the island of Rhodes (Greece), revealed by morphological and phylogenetic analysis (Crustacea, Amphipoda, Talitridae). Zookeys 652: 37-54.

Davolos D, De Matthaeis E, Latella L, Tarocco M, Özbek M, Vonk R. 2018a. On the molecular and morphological evolution of continental and insular Cryptorchestia species, with an additional description of C. garbinii (Talitridae). Zookeys 783: 37-54.

Davolos D, Vonk R, Latella L, De Matthaeis E. 2018b. The name of a model species: the case of Orchestia cavimana (Crustacea: Amphipoda: Talitridae). Eur Zool J 85: 228-230.

Galil BS, Nehring S, Panov V. 2008. Waterways as invasion highways - impact of climate change and globalization. In: Nentwig W, ed. Biological invasions. Ecological Studies (Analysis and Synthesis), Springer, Berlin, Heidelberg, 59-74.

GBIF.org (06 November 2019) GBIF Occurrence Download https:// doi.org/10.15468/dl.igspzu

Grabowski M, Jażdżewski K, Konopacka A. 2007. Alien Crustacea in Polish waters - Amphipoda. Aquat Invasions 2: 25-38.

Grabowski M, Rewicz T, Bącela-Spychalska K, Konopacka A, Mamos T, Jażdżewski K. 2012. Cryptic invasion of Baltic lowlands by freshwater amphipod of Pontic origin. Aquat Invasions 7: 337-346.

Grabowski M, Mamos T, Bącela-Spychalska K, Rewicz T, Wattier R. 2017. Neogene paleogeography provides context for understanding the origin and spatial distribution of cryptic diversity in a widespread Balkan freshwater amphipod. PeerJ 5: e3016.

Gruszka P. 1999. The River Odra estuary as a gateway for alien species immigration to the Baltic Sea basin. Acta Hydrochim Hydrobiol 27: 374-382.

Gruszka P, Rokicka-Praxmajer J, Cupak J, Radziejewska T, Wolska M. 2013. Unintended "biological cargo" of ships entering the River Odra estuary: Assemblages of organisms in ballast tanks. Zesz Nauk/Akad Morska w Szczec 33: 22-29.

Herkül JK, Kotta J, Kotta I. 2006. Distribution and population characteristics of the alien talitrid amphipod Orchestia cavimana in relation to environmental conditions in the Northeastern Baltic Sea. Helgol Mar Res 60: 121-126.

Hupało K, Grabowski M. 2018. A first insight into the transatlantic population genetic structure of the beach flea, Platorchestia platensis (Krøyer, 1845). Bioinvasions Rec 7: 165-170.

Jabłońska A, Szlauer-Łukaszewska A, Bańkowska A. 2015. Aulodrilus pigueti Kowalewski, 1914 (Annelida: Clitellata) a new record for the Polish fauna from the Oder River and remarks on other oligochaetes rarely noticed in Poland. Oceanol Hydrobiol Stud 44: 456-465.

Jabłońska A, Mamos T, Gruszka P, Szlauer-Łukaszewska A, Grabowski M. 2018. First record and DNA barcodes of the aquarium shrimp, Neocaridina davidi, in Central Europe from thermally polluted River Oder canal, Poland. Knowl Manag Aquat Ecosyst 419: 14

Jabłońska A, Wrzesińska W, Zawal A, Pešić V, Grabowski M. 2020. Long term within basin isolation patterns, different conservation units, and interspecific mitochondrial DNA introgression in an amphipod endemic to the ancient Lake Skadar system, Balkan Peninsula. Freshw Biol 65: 209-225.

Jażdżewski K, Konopacka A. 1995. Pancerzowce prócz równonogów lądowych (Malacostraca excl. Oniscoidea). Katalog fauny Polski 1(13). Polskie Wydawnictwo Naukowe, Warszawa, 165 p. [In Polish].

Jelassi R, Khemaissia H, Nasri-Ammar K. 2018. Biodiversity of Amphipoda Talitridae in Tunisian Wetlands. In Bulent S, Grillo O, eds, Selected Studies in Biodiversity, IntechOpen, United Kingdom, London, 101-118.

Juhász P, Kovács K, Szabó T, Csipkés R, Kiss B, Müller Z. 2006. Faunistical results of the Malacostraca investigations carried out in the frames of the ecological survey of the surface waters of Hungary (ECOSURV) in 2005. Fol Hist Nat Mus Matr 30: 319-323.

Karaman G. 1993. Crustacea Amphipoda di acqua dolce. Fauna d'Italia. Edizione Calderini, Bologna, 337 p.

Kearse M, Moir R, Wilson A, et al. 2012. Geneious Basic: an integrated and extendable desktop software platform for the organization and analysis of sequence data. Bioinformatics 28: $1647-1649$

Kimura M. 1980. A simple method for estimating evolutionary rate of base substitutions through comparative studies of nucleotide sequences. J Mol Evol 16: 111-120.

Konopacka A, Grabowski M, Bącela-Spychalska K, Rewicz T. 2009. Orchestia cavimana Heller, 1865 (Amphipoda: Talitridae) enters freshwater inland habitats in the Vistula River. Aquat Invasions 4: 689-691.

Leuven RS, van der Velde G, Baijens I, et al. 2009. The river Rhine: A global highway for dispersal of aquatic invasive species. Biol Invasions 11: 1989-2008.

Librado P, Rozas J. 2009. DnaSP v5: a software for comprehensive analysis of DNA polymorphism data. Bioinformatics 25: 1451-1452.

Lowry JK, Fanini L. 2013. Substrate dependent talitrid amphipods from fragmented beaches on the north coast of Crete (Crustacea, Amphipoda, Talitridae), including a redefinition of the genus Orchestia and descriptions of Orchestia xylino sp. nov. and Cryptorchestia gen. nov. Zootaxa 3709: 201-229.

Mamos T, Wattier R, Burzyński A, Grabowski M. 2016. The legacy of a vanished sea: a high level of diversification within a European freshwater amphipod species complex driven by 15 My of Paratethys regression. Mol Ecol 3: 795-810.

Martens A, Eggers TO, Grabow K. 1999. Erste Funde von Pontogammarus robustoides (Sars) im Mittellandkanal (Crustacea: Amphipoda). Lauterbornia 35: 39-42.

Mauvisseau Q, Davy-Bowker J, Bryson D, Souch GR, Burian A, Sweet M. 2019. First detection of a highly invasive freshwater amphipod Crangonyx floridanus (Bousfield, 1963) in the United Kingdom. Bioinvasions Rec 8: 1-7.

Messner U, Zettler ML. 2018. The conquest (and avoidance?) of the brackish environment by Ponto-Caspian amphipods: a case study of the German Baltic Sea. BioInvasions Rec 7: 269-278.

Osadczuk A. 2004. Zalew Szczeciński. Środowiskowe warunki współczesnej sedymentacji lagunowej. Wydawnictwa Naukowe Uniwersytetu Szczecińskiego, Rozprawy i studia 549, Szczecin, $156 \mathrm{p}$ [In Polish].

Pabis K, Krodkiewska M, Cebulska K. 2017. Alien freshwater polychaetes Hypania invalida (Grube 1860) and Laonome calida 
Capa 2007 in the Upper Odra River (Baltic Sea catchment area). Knowl Manag Aquat Ecosyst 418: 46.

Rachalewski M, Konopacka A, Grabowski M, Bącela-Spychalska K. 2013. Echinogammarus trichiatus (Martynov, 1932) - a new Ponto-Caspian amphipod invader in Poland with remarks on other alien amphipods from the Oder river. Crustaceana 86: 1224-1233.

Ramm T, Scholtz G. 2017. No sight, no smell? e Brain anatomy of two amphipod crustaceans with different lifestyles. Arthropod Struct Dev 46: $537 \mathrm{e} 551$.

Ratnasingham S, Hebert PD. 2007. BOLD: The Barcode of Life Data System (http://www.barcodinglife.org). Mol Ecol Resour 7: 355-364.

Ratnasingham S, Hebert PD. 2013. A DNA-based registry for all animal species: the Barcode Index Number (BIN) system. PloS ONE 8: e66213.

Rehage HO. 1987. Zum weiteren Vordringen von Orchestia cavimana Heller, 1865 (Crustacea, Talitridae) in Westfalen. Natur und Heimat 47: 41-44.

Rewicz T, Wattier R, Grabowski M, Rigaud T, Bącela-Spychalska K. 2015. Out of the Black Sea: Phylogeography of the invasive killer shrimp Dikerogammarus villosus across Europe. PLOS ONE 10: e0118121.

Rewicz T, Konopacka A, Bącela-Spychalska K, Özbek M, Grabowski M. 2016. First records of two formerly overlooked Ponto-Caspian amphipods from Turkey: Echinogammarus trichiatus (Martynov, 1932) and Dikerogammarus villosus (Sovinsky, 1894). Turk J Zool 40: 328-335.

Rewicz T, Grabowski M, Tończyk G, Konopacka A, BącelaSpychalska K. 2019. Gammarus tigrinus Sexton, 1939 continues its invasion in the Baltic Sea: first record from Bornholm (Denmark). Bioinvasions Rec 8: 862-870.

Ruffo S, Tarocco M, Latella L. 2014. Cryptorchestia garbinii n. sp. (Amphipoda: Talitridae) from Lake Garda (Northern Italy), previously referred to as Orchestia cavimana Heller, 1865, and notes on the distribution of the two species. Ital J Zool 81: 92-99.
Saitou N, Nei M. 1987. The neighbor-joining method: A new method for reconstructing phylogenetic trees. Mol Biol Evol 4:406-425.

Spicer JI, Janas U. 2006. The beachflea Platorchestia platensis (Krøyer, 1845): a new addition to the Polish fauna (with a key to Baltic talitrid amphipods). Oceanologia 48: 287-295.

Sworobowicz L, Grabowski M, Mamos T, et al. 2015. Revisiting the phylogeography of Asellus aquaticus in Europe: insights into cryptic diversity and spatiotemporal diversification. Freshw Biol 60: $1824-1840$

Szlauer-Łukaszewska A, Grabowski M. 2012. First record of Jaera istri Veuille, 1979 (Isopoda, Janiridae) in Poland: eastward invasion from the Mittelland Canal. Crustaceana 85: 1333-1338.

Szlauer-Łukaszewska A, Andrzejewski W, Gierszal H, Urbańska M. 2017. Occurrence of Sinanodonta woodiana with the native Unionidae in the lower Oder. Oceanol Hydrobiol Stud 46: 244-248.

Tamura K, Stecher G, Peterson D, Filipski A, Kumar S. 2013. MEGA6: Molecular Evolutionary Genetics Analysis version 6.0. Mol Biol Evol 30: 2725-2729.

Tykarska M, Janas U, Brzana R. 2019. Distribution and abundance of Talitridae in the southern Baltic Sea - twelve years after the first record of Platorchestia platensis (Krøyer, 1845) in 2005. Oceanol Hydrobiol Stud 48: 66-75.

Wildish DJ, Pavesi L, Ketmaier V. 2012. Talitrid amphipods and the driftwood ecological niche: a morphological and molecular study. $J$ Nat Hist 46: 2677-2700.

Wolff C, Scholtz G. 2006. Cell lineage analysis of the mandibular segment of the amphipod Orchestia cavimana reveals that the crustacean paragnaths are sternal out-growths and not limbs. Front Zool 3: 19.

Wysocka A, Grabowski M, Sworobowicz L, et al. 2013. A tale of time and depth: intralacustrine radiation in endemic Gammarus species flock from the ancient Lake Ohrid. Zool J Linn Soc 167: 345-359.

Zettler ML, Zettler A. 2017. Marine and freshwater Amphipoda from the Baltic Sea and adjacent territories. Conchbooks, Harxheim, 845 p.

Cite this article as: Rewicz T, Brodecki J, Bącela-Spychalska K, Konopacka A, Grabowski M. 2020. Further steps of Cryptorchestia garbinii invasion in Polish inland waters with insights into its molecular diversity in Central and Western Europe. Knowl. Manag. Aquat. Ecosyst., 421, 17. 